PRZEGLĄD BIBLIOTECZNY 2017 z. 1

PL ISSN 0033-202X

\author{
MIKOŁAJ OCHMAŃSKI
}

Wydział Dziennikarstwa, Informacji i Bibliologii

Uniwersytet Warszawski

e-mail: m.ochmanski@uw.edu.pl

\title{
CZY WIKIPEDIA MOŻE BYĆ PRZYDATNA W NAUCZANIU HISTORII KSIĄŻKI I BIBLIOTEK?
}

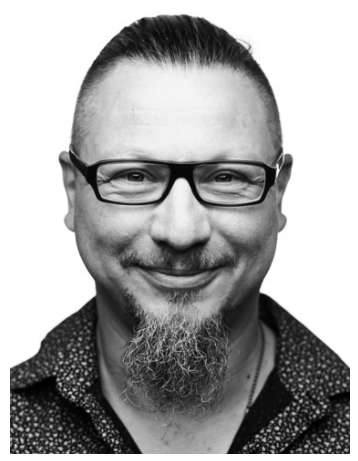

Mikołaj Ochmański - dr, adiunkt w Katedrze Książki i Historii Mediów na Wydziale Dziennikarstwa, Informacji i Bibliologii Uniwersytetu Warszawskiego. Z kierunkiem bibliotekoznawczym na UW związany jest od ponad 30 lat, najpierw jako student, następnie pracownik naukowo-dydaktyczny. Jego zainteresowania badawcze i działalność dydaktyczna koncentrują się wokół zagadnień kultury książki, zarówno w aspekcie historycznym (rozprawa doktorska na temat XVII-wiecznych druków okolicznościowych w Królewcu, zajęcia z zakresu historii książki i bibliotek), jak i współczesnym (m.in. problematyka książki i jej miejsce we współczesnej kulturze cyfrowej). Ponadto jest zaangażowany w społeczny ruch naukowy, pełni funkcję prezesa Zarządu w Oddziale Warszawskim Polskiego Towarzystwa Bibliologicznego i w ramach prac Stowarzyszenia uczestniczy w organizacji konferencji naukowych poświęconych tematyce bibliologicznej (ostatnia dotyczyła związków między książką a technologiami), w realizacji projektów oraz publikacji książek naukowych.

SŁOWA KLUCZOWE: Bibliologia historyczna. Wikipedia. Historia książki. Historia drukarstwa. Kształcenie bibliotekoznawcze.

ABSTRAKT: Teza/cel artykułu - Celem artykułu jest przedstawienie Wikipedii jako źródła informacji na temat historii książki polskiej XV i XVI w., przydatności treści w popularyzacji wiedzy na temat historii książki oraz w dydaktyce bibliotekoznawczej. Przeanalizowano wybrane hasła dotyczące historii książki polskiej XV-XVI w., wykazano błędy, nieścisłości, braki, ale też przyjrzano się korektom błędnych treści, dokonanym przez wikipedystów. 
Zaproponowano sposób wykorzystania Wikipedii z jej błędami i zaletami w nauczaniu historii książki. Metody badawcze - Podstawę artykułu stanowią materiały dotyczące historii drukarstwa polskiego XV-XVI w. zaczerpnięte z Wikipedii. Zastosowano metodę analizy i krytyki treści zawartych w Wikipedii. Wyniki i wnioski - Wykazano błędy w artykułach Wikipedii i podano w wątpliwość jej wartość informacyjną w odniesieniu do treści na temat historii książki, ukazano zalety, jakie wynikają ze społecznościowego współtworzenia treści internetowej encyklopedii, wskazano możliwości jej wykorzystania w dydaktyce bibliotekoznawczej na przykładzie zajęć dotyczących historii książki i bibliotek.

\section{BIBLIOLOGIA, CZYLI O ROZUMIENIU KULTURY}

Kazimierz Piekarski przed ponad osiemdziesięciu laty w artykule, który wpisał się do klasyki polskiej nauki o książce, dał wyraz refleksji nad znaczeniem bibliologii. Napisał mianowicie „Można śmiało stwierdzić, że nie bylibyśmy w stanie zrozumieć całokształtu dziejów nowożytnych, gdybyśmy z rozważań naszych wyłączyli - książkę. Oczywistość tego faktu dała rezultaty poniekąd dziwne. Oto książka i jej społeczne funkcje w przebiegu dziejowym nie stały się dotychczas wcale przedmiotem samodzielnej i uznanej dyscypliny naukowej" (Piekarski, 1932, s. 353). Artykuł ukazał się w pracy zbiorowej Kultura staropolska wśród tekstów takich uczonych jak Kazimierz Dobrowolski, Aleksander Brückner, Julian Krzyżanowski czy Stanisław Kot. Książka drukowana XV i XVI w. została przedstawiona jako jeden $z$ fundamentalnych elementów i zarazem narzędzi polskiej kultury na przestrzeni stuleci.

Dziś operujemy w obszarze badawczym nauki, która od kilku lat figuruje $\mathrm{w}$ wykazie obszarów wiedzy, dziedzin nauki i sztuki oraz dyscyplin naukowych i artystycznych pod nazwą bibliologia i informatologia (Rozporządzenie, 2011). Bibliologia, po kilkudziesięciu latach różnych prób, została zdefiniowana jako ta dyscyplina pośród nauk humanistycznych, której centralnym problemem badawczym stała się kultura książki (Migoń, 2007, s. 15). Niejako odpowiedzią na kwestię postawioną przez Piekarskiego i wyzwaniem dla kolejnych pokoleń bibliologów są słowa Krzysztofa Migonia: „Kultura książki stając się centralnym przedmiotem badań w bibliologii, daje szansę pełnego i pogłębionego opisu fenomenu książki jako wytworu i narzędzia kultury, objęcia całego światowego dziedzictwa książkowego w jego różnorodnych przejawach i funkcjach. Umieszczona pośród innych zjawisk kultury dowodzi swojego znaczenia w rozwoju cywilizacji, dzisiaj w całej rozległości jeszcze nie dostrzeganego" (Migoń, 2008, s. 18).

Książka jest, w tym książka z pierwszych wieków drukarstwa polskiego, słusznie postrzegana zarazem jako ważny element kultury i jej przedmiot, ale też podmiotowo, jako narzędzie tworzenia i rozwoju dorobku kulturalnego. Oczywiste jest mówienie o druku, w tym o książce drukowanej, jako o medium, które spowodowało zmiany świata nowożytnego, stało się za- 
równo narzędziem przemian szybkich, rewolucyjnych, jak i ewolucyjnego przekształcania kultury. Warto zatem o niej mówić, warto popularyzować wiedzę o książce, zwłaszcza że, jeszcze raz przywołując słowa Migonia, mówimy o medium, którego rola w dziejach kultury nie jest w pełni dostrzegana. Tym samym bibliologia, chociaż przedmiotem jej refleksji jest niemal wszechobecna książka i jej kulturotwórcze znaczenie, wydaje się pozostawać na marginesie nauk, nieraz postrzegana jako dyscyplina pomocnicza historii, czy historii literatury.

Bibliologię popularyzować można na różne sposoby. Będą wśród nich m.in. książki oraz artykuły w prasie popularnonaukowej i społecznej, wykłady uniwersytetu otwartego, panele dyskusyjne na targach książki, czy imprezy organizowane przez biblioteki. Zaliczyć do nich też trzeba środki komunikacji elektronicznej odpowiadające potrzebom cyfrowych tubylców. Popularność urządzeń komunikacji cyfrowej i mobilnych oraz powszechny dostęp do Internetu powoduje, że korzystanie z zasobów cyberprzestrzeni jest coraz prostsze i coraz częstsze (Główny Urząd Statystyczny, 2015; Mobile online, 2015; Wyniki badań Gemius, 2016). Jednym z najpopularniejszych zasobów wiedzy w cyberprzestrzeni jest Wikipedia. Już to samo predestynuje ją do roli narzędzia służącego popularyzacji nauki o książce.

\section{UCZESTNICTWO W KULTURZE, CZYLI PROSUMENCI}

Medium, które obecnie jest postrzegane jako narzędzie istotnych współczesnych zmian, a zarazem wydaje się bardzo skutecznym narzędziem promocji, w tym także promocji kultury i wiedzy o niej, jest Internet. Jest on też narzędziem uczestniczenia w kulturze i to na sposób odmienny niż dotychczasowy.

Uczestnictwo w kulturze zmienia się, wpływ na nie mają technologie informacyjne. Przy ich wykorzystaniu pojawiły się nowe formy aktywności kulturalnej, kanały odbioru dóbr kultury oraz sposoby jej (współ)tworzenia. Oprócz tradycyjnego w istocie, chociaż realizowanego za pośrednictwem nowoczesnych technologii cyfrowych uczestnictwa w kulturze, jak wyszukiwanie informacji związanych z kultura, odtwarzanie filmów i muzyki, granie w gry, czytanie i/lub pobieranie czasopism oraz kupowanie książek elektronicznych, wyszukiwanie informacji na temat sportu i rozrywki (Główny Urząd Statystyczny, 2009), pojawiają się aktywności, których efektem jest współtworzenie zawartości zasobów sieciowych. Do nowych form uczestniczenia w kulturze, które pojawiły się wraz z rozwojem technologii cyfrowych, zaliczyć można m.in. aktywność na portalach społecznościowych i blogach, czy chociażby działalność popularnych tzw. youtuberów. Mamy do czynienia z nurtem kultury zdecentralizowanej, zdehierarchizowanej, rozwijającej się oddolnie, w społecznej kooperacji (Majewski, 2013, s. 26-27). Kultury prosumentów. 
Pojęcie prosument na określenie osoby, która zarazem jest producentem i konsumentem pojawia się w latach 70. XX w. w pracy Marshalla McLuhana i Barringtona Nevitta Take today (McLuhan, Nevitt, 1972). Rozwinął je Alvin Toffler w Trzeciej fali (Toffler, 2006). Nurt prosumencki wyszedł poza zjawiska ekonomiczne. Odgrywa dużą rolę w odbiorze, tworzeniu, ale również w promocji dóbr kultury. Stąd chociażby obecność profilów instytucji kultury w portalach społecznościowych, tworzenie tzw. fanpage'y i/lub wydarzeń, jako sposobu informowania o planowanych aktywnościach i ich promowania. Szczególną cechą promocji za pośrednictwem narzędzi społecznościowych jest otwarcie się na odbiorców, którzy stają się również nadawcami komunikatu, współtwórcami wyrażającymi swoje opinie, zachęcającymi innych użytkowników Internetu, dopisują dodatkowe informacje, uzupełniają materiał własnymi zdjęciami lub filmami, odsyłają do podobnych wydarzeń. Sieć 2.0 stała się zatem obszarem zarówno promowania kultury, jak i promowania aktywności użytkowników, zaangażowania $w$ kulturę, w weryfikowanie dostępnych treści, w ich współtworzenie, a co za tym idzie odpowiedzialności za nie.

Szczególnym forum działalności prosumenckiej jest Wikipedia. Jej wyjątkowość polega na ogromnym zasięgu (znajduje się w pierwszej dziesiątce najczęściej odwiedzanych stron w Polsce) i roli w kształtowaniu wiedzy użytkowników. Większość internautów ogranicza się do szukania informacji w encyklopedii. Jest jednak duża grupa autorów i redaktorów jej treści. Według statystyk polska wersja Wikipedii ma 34706 zarejestrowanych wikipedystów (Statystyki Wikipedii). Wśród nich są zarówno specjaliści, amatorzy o dużej wiedzy, jak i, niestety, dyletanci. Jedni i drudzy są odpowiedzialni za stan wiedzy odbiorców Wikipedii, którą współtworzą. By ograniczyć liczbę błędów, w Wikipedii opracowano mechanizmy weryfikacji i zatwierdzania treści. Niestety, zdarza się, że zawodzą, co dostrzec można na przykładach zaczerpniętych z artykułów dotyczących historii książki. Jednak na tych samych przykładach pokazać można, w jaki sposób przyjęte w Wikipedii narzędzia i sposoby kontroli wpływają na poprawianie treści, tym samym na ciągły wzrost wartości encyklopedii. Więcej, mechanizmy wypracowane przez wikipedystów w celu doskonalenia encyklopedii, mogą stać się z powodzeniem narzędziem dydaktyki z zakresu dziejów książki (m.in. śledzenie zmian, wyszukiwanie braków i błędów oraz ich poprawianie).

WIKIPEDIA, CZYLI POPULARNE NARZĘDZIE POPULARYZACJI WIEDZY

Początki Wikipedii sięgają 2000 r. i biorą się z projektu Nupedia (Jemielniak, 2013, s. 28). Według danych ze strony polskiej edycji Wikipedii (aktualizacja strony dn. 14 lutego 2017 r.), rodzima wersja zawiera 
1207448 artykułów (Wikipedia: statystyki). Liczba artykułów, nawet jeśli nie jest precyzyjna, świadczy o dużej popularności projektu w Polsce (wśród osób polskojęzycznych) i nie tylko biernym korzystaniu z zasobów projektu, ale też o zaangażowaniu w tworzenie jego zawartości. Ponadto coraz częściej Wikipedia i narzędzia Wikimedia postrzegane są także przez instytucje jako sposób prezentacji zasobów i promocji. We wrześniu 2015 r. współpracę z Wikimedia Polska w zakresie udostępniania kopii cyfrowych zbiorów muzealnych w repozytorium Wikipedii rozpoczęło Muzeum Narodowe w Warszawie. Jest to pierwszy tego rodzaju projekt w Polsce.

\section{WIKIPEDIA, CZYLI TAKŻE O HISTORII KSIĄŻKI}

Wydaje się, że ze względu na encyklopedyczną funkcję projektu i jego popularność, polska Wikipedia powinna stanowić forum promocji wiedzy na temat książki i jej roli w historii kultury. Pytanie, na ile taką rolę pełni oraz na ile przedstawiane przez autorów amatorów informacje są wiarygodne?

Informacje na temat początków drukarstwa polskiego w Wikipedii znajdujemy rozproszone w kilkudziesięciu artykułach: od krótkich biogramów drukarzy, przez obszerniejsze omówienia działalności poszczególnych oficyn, aż po artykuły przekrojowe. Przede wszystkim zwięzłe opisanie historii typografii w Rzeczpospolitej znalazło się pod hasłem „Drukarstwo polskie". W obecnej wersji artykuł mimo pewnych nieścisłości i braków może stanowić punkt wyjścia do dalszych poszukiwań informacji na temat historii książki drukowanej w Polsce. Przez lata jednak nie tylko nie oddawał podstawowej wiedzy na ten temat, ale również nie odsyłał do współczesnej literatury przedmiotu. Wcześniejsze edycje, poczynając od pierwszej, były nawet kuriozalne. Autor powołujący się na Encyklopedię Powszechna Kieszonkowa z 1888 r. w lipcu 2008 r. podał, że (zachowano pisownię oryginału): „Pierwszą drukarnię w Polsce założył Gŭnther Zeiner w Krakowie w 1465, drugim drukarzem po nim był Świętopełk Fiol, który drukował pierwszy na świecie książki słowiańskie. Pierwszą stałą drukarnię założył w Krakowie w 1505 Jan Haller, następnie również w Krakowie Hieronim Wietor, ślązak, a także Szafenbergerowie, Floryan Ungier. Ogółem w Krakowie 7 drukarń, w 1610 już 10. Drukarstwo zaczęło chylić się ku upadkowi około 1615 przyciśnięte nietolerancją duchowieństwa. W 1650 pozostały tylko 3 drukarnie świeckie, lecz natomiast kilka zakonnych. Do 1707 w Warszawie istniała tylko jedna drukarnia Pijarów. Drukarstwo rozwijać sie poczęło dopiero za panowania Stanisława Augusta" (Drukarstwo polskie: różnice pomiędzy wersjami). Przytoczona została treść całego artykułu, niczego więcej nie można było się z niego dowiedzieć. Tekst ten, mimo kolejnych edycji innych autorów, głównie uzupełnień o fakty z wieków XVII i XVIII, pozostawał przez kilka lat niezmieniony. Dopiero pod koniec lutego 2013 r., inny z wikipedystów zastąpił go fragmentem brzmiącym: „Po wy- 
nalezieniu ruchomej czcionki przez Jana Gutenberga sztuka typograficzna szybko rozprzestrzeniła się po Europie. Polska była 9 krajem z kolei, do którego dotarli drukarze z Niemiec, wędrujący w poszukiwaniu miejsc, w których mogliby prowadzić swoje oficyny. Pierwsze warsztaty funkcjonowały przez krótki czas, na ogół przez kilka lat, a ich produkcja nie była pokaźna. Za pierwszego drukarza na ziemiach polskich uważany jest Kasper Straube, który przybył do Krakowa z Bawarii. Jego drukarnia funkcjonowała w latach 1473-1477. Spod jego pras wyszły cztery druki. Kolejnym drukarzem, również pracującym w Krakowie był Szwajpolt Fiol z Frankonii. Drukował księgi liturgiczne cyrylicą od 1491 roku, ale wobec oskarżenia o herezję musiał przerwać pracę". Dodano jeszcze kilka uzupełniających akapitów na temat drukarstwa XVI w. (Drukarstwo polskie: różnice pomiędzy wersjami). W obydwu przypadkach celowo w cytatach zachowana została pisownia oryginałów, by pokazać jakość wpisów. W dalszym ciągu artykuł pozostawiał niedosyt i wymagał poprawek edytorskich, jednak przynajmniej nie był sprzeczny z dzisiejszym stanem wiedzy.

Przez prawie pięć lat informacje dotyczące początków drukarstwa w Polsce pochodziły z XIX-wiecznej encyklopedii i były nie tylko niezgodne z dzisiejszą wiedza, ale też bardzo ubogie. Opieranie się na nich dawało fałszywy obraz, użytkownicy korzystający wyłącznie z Wikipedii nie dość, że byli wprowadzeni w błąd, to jeszcze nie otrzymywali wskazówek, co do współczesnej literatury przedmiotu, w której mogliby zweryfikować podane informacje. Wieloletnie trwanie przy tej anachronicznej treści jest tym bardziej zaskakujące, że modyfikacji artykułu dokonywało w tym czasie 10 osób.

Wersja dzisiejsza, dostępna w dniu 15 września 2015 r., edycja datowana na 9 kwietnia 2015 r., zwięźle informuje o wszystkich znanych typografach polskich działających w XV w., także o tych, co do których działalności mamy jedynie przesłanki archiwalne (Jan Pepelau, Jan Krueger). Nie wspomniano natomiast o działającym w Sewilli polskim drukarzu Stanisławie Polaku, którego postać w ogóle nie pojawia się na łamach Wikipedii.

Całość artykułu obejmuje historię drukarstwa polskiego od XV w. do lat 20. XIX stulecia i podzielona została na kilka części. Dwa krótkie zdania wstępne lokują początki polskiego drukarstwa w czasie. Mowa również o kalendarzu wydrukowanym przez Kaspra Straubego (bardzo lakoniczna wzmianka). Przy okazji należy zauważyć brak w polskiej wersji Wikipedii hasła dotyczącego Almanachu z 1474 r. Wydawałoby się, że informacji o pierwszym druku na ziemiach polskich nie powinno zabraknąć. Tym bardziej, że wersja anglojęzyczna ma odrębny artykuł pod hasłem „Almanach cracoviense ad annum 1474" (Almanach cracoviense ad annum 1474). Wracając do artykułu dotyczącego dziejów drukarstwa w Rzeczpospolitej, pierwsza część opisowa nosi tytuł „Drukarstwo staropolskie”, obejmuje 
następujące zagadnienia: pierwsi drukarze na ziemiach polskich, drukarstwo w XVI w., drukarstwo różnowierców (zawiera podpunkty: kalwinizm, arianizm, luteranizm, prawosławie, drukarstwo hebrajskie). Część druga została zatytułowana „Drukarstwo w epoce Oświecenia” podzielona jest na: drukarnie warszawskie, drukarnie w innych miastach (Kraków, Gdańsk, Zamość, Wilno, Lwów, Lublin, Wrocław, Królewiec) oraz tabelaryczne zestawienie pt. Ośrodki w pozostałych miastach (chronologicznie), w którym wymieniono w porządku chronologicznym zakładania drukarń 36 ośrodków.

Mimo naniesionych zmian i uzupełnień, treść artykułu wciąż budzi wątpliwości. Historia drukarstwa w XVI w., czyli okresu dynamicznego kształtowania się rynku polskiej książki, została sprowadzona do jednego krótkiego akapitu, z którego można wnioskować, że poza Krakowem, w którym działali Jan Haller, Florian Ungler oraz Hieronim Wietor, drukarstwo nie tyle nie rozwijało się, co w ogóle nie istniało. Dopiero wczytanie się we fragmenty dotyczące oficyn różnowierczych daje pełniejszy obraz drukarstwa polskiego XVI w., chociaż wciąż pozostawia niedosyt. Kolejnych informacji na temat drukarstwa XVI-wiecznego można doszukać się dopiero w części pt. „Drukarstwo w epoce Oświecenia”. Zostały one podane w opisach poszczególnych miast. Skutkiem niefortunnego uporządkowania treści z lektury tekstu można wywnioskować, że autorzy artykułu oświecenie traktują dość szeroko stawiając jego granice między latami 1538 (mylnie podane początki drukarstwa w Gdańsku) i 1830.

Wątpliwość może budzić też zastosowanie kryterium oświecenia typowego dla historii literatury z jego datą końcową sięgającą lat 20. XIX w. do uporządkowania dziejów książki. W polskiej bibliologii historycznej zwykło się używać cezury 1800 r., jako końca epoki starych druków i ma to uzasadnienie w pojawiających się nowych zjawiskach, związanych z produkcją książki, a nie w zmianach w kulturze literackiej. Nie należy jednak traktować takiego postawienia sprawy jako błędu, raczej jako odstępstwo od przyjętej w polskiej nauce o książce cezury, a co za tym idzie świadectwo prawdopodobnie słabej orientacji autorów artykułu w zagadnieniach i lekturach bibliologicznych.

Istotnych braków i pomyłek można znaleźć więcej. Użytkownik Wikipedii nie trafi $\mathrm{w}$ artykule dotyczącym historii polskiego drukarstwa na wzmiankę nawet o Kasprze Hochfederze, który przy wsparciu i w domu Jana Hallera założył pierwszą w XVI w. drukarnię krakowską, więcej, była to oficyna, która rozpoczęła ciągłość drukarstwa w Polsce. O Hochfederze brak w ogóle wzmianki w Wikipedii (Drukarze dawnej Polski, 1983, s. 64). Pod hasłem dotyczącym historii drukarstwa próżno też szukać wiadomości o działaniu bardzo zasłużonej dla rozwoju drukarstwa polskiego rodziny Szarfenbergów. W Wikipedii zamieszczono natomiast oddzielny artykuł "Szarfenbergerowie - rodzina" (Szarfenbergerowie (rodzina)). Brak chociaż 
podstawowych danych na temat Łazarza Andrysowicza, pierwszego kierownika drukarni o rdzennie polskich korzeniach (Drukarze dawnej Polski, 1983, s 125). Natomiast poświęcone jemu oraz jego drukarni są aż dwa oddzielne artykuły - bardzo ubogi w treść biogram (Łazarz Andrysowicz) oraz obszerniejsze dzieje oficyny (Drukarnia Łazarzowa). Podobnie ma się sprawa z synem Łazarza, drukarzem Jana Kochanowskiego i pierwszego wydania Biblii Jakuba Wujka - Janem Januszowskim. Dla postaci bardzo ważnej w historii polskiego drukarstwa i kultury, m.in. tłoczył Nowy karakter polski, a w nim swój Wstępek do Ortografijej polskiej (Drukarze dawnej Polski, 1983, s. 70), zabrakło miejsca w omawianym artykule. Jest jednak odrębny, wystarczający jak na miary encyklopedii tekst jemu poświęcony (Jan Januszowski). Również Maciej Wirzbięta, drukarz utworów Mikołaja Reja i pism powstałych w środowisku małopolskich kalwinistów (Drukarze dawnej Polski, 1983, s. 359) nie pojawia się w Drukarstwie polskim. Jemu także poświęcono odrębny artykuł (Maciej Wirzbięta).

Oczywiście, że encyklopedia o charakterze powszechnym nigdy nie będzie dawać pełnej i kompletnej informacji dotyczącej zjawisk szczegółowych. Wystarczyłoby jednak, przynajmniej w odniesieniu do XVI w., wymienić nazwiska najważniejszych polskich typografów i zastosować odsyłacze do odrębnych artykułów w Wikipedii. Przede wszystkim ze względu na ich rolę w kształtowaniu nowego medium, we wprowadzaniu go na polski rynek, co w efekcie zmieniło w sposób znaczący komunikację, kulturę, naukę, politykę, życie religijne i społeczne Rzeczypospolitej. Wreszcie XVI w. to czas, w którym drukarze podjęli pierwsze inicjatywy uporządkowania polskiej ortografii, i w którym ukazały się pierwsze książki w języku polskim. Wspomniano już chociażby o niezauważonej przez autorów hasła inicjatywie Jana Januszowskiego. W artykule jest jednak mowa o innym przedsięwzięciu: „Wydawcą pierwszej drukowanej książki w języku polskim był Florian Ungler, którego drukarnia działała w latach 1510-1551" (Drukarstwo polskie. Drukarstwo w XVI wieku).

O ile o kompletności można dyskutować i mieć różne opinie na temat obszerności i szczegółowości artykułów, o tyle błędy merytoryczne i pomyłkowe zapisy bez wątpienia są nie do przyjęcia i rzucają cień na wiarygodność prezentowanych treści, a przynajmniej na solidność autorów. Zdarzają się $\mathrm{w}$ artykule drobne pomyłki, jak chociażby błąd w nazwisku pierwszego drukarza z Malborka, Jakuba Karweyse (jest Kraweyse), które utrudniają wyszukiwanie informacji, ale wymagają jedynie zabiegów korektorskich. Gorzej, gdy trafiają się błędy merytoryczne, które skutkują fałszywą wiedzą u czytelników przyjmujących informacje czerpane z Wikipedii bezkrytycznie. Tak jest chociażby w przypadku wspomnianej już historii drukarstwa w Gdańsku: „Pierwszą drukarnię, w 1538 r., założył Franciszek Rhode. Ale właściwy twórca drukarstwa w Gdańsku to Holender, Franciszek Rohde, który założył w 1538 r. przy ul. Rzeźnickiej pierwszą oficynę" 
(Drukarstwo polskie. Gdańsk). Pomijając niezbyt zrozumiałą konstrukcję językową, świadczącą o dużym niechlujstwie autora tekstu, warto przypomnieć, że drukarstwo gdańskie zaczęło się jeszcze w XV w., o czym zresztą jest mowa w tym samym artykule wcześniej, a w XVI w. w mieście działali Marcin Tretter (1505-1506) i Jan Weinreich (1520-1523). Owszem, Franciszek Rhode założył w 1538 r. pierwszą długotrwałą oficynę w Gdańsku, a jego syn Jakub, po przejęciu tłoczni, publikował liczne polonika (Drukarze dawnej Polski, 1962, s. 117-120). Również błędnie opisane są początki drukarstwa w Warszawie. W artykule nie wspomina się o fakcie arcyważnym dla polskiej kultury i literatury opublikowania Odprawy posłów greckich Jana Kochanowskiego przez drukarnię latającą Mikołaja Szarfenbergera pod kierownictwem Jana Łapki Łapczyńskiego właśnie w Warszawie w 1578 r. (Kawecka-Gryczowa, 1971). Był to pierwszy warszawski druk. Co ciekawe w oddzielnym artykule poświęconym Odprawie fakt ten został odnotowany (Odprawa postów greckich).

Są to przykłady poważnych błędów merytorycznych w artykule, które przy zaufaniu użytkowników do Wikipedii i przy łatwym oraz szybkim dostępie do niej mogą skutkować utrwalaniem fałszywej wiedzy na temat dziejów polskiej książki drukowanej.

Kolejnym błędem, czy może lepiej powiedzieć niedociągnięciem artykułu „Drukarstwo polskie”, jest przyjęta struktura treści. Skutkiem zastosowanego układu rozmyty został obraz drukarstwa Rzeczypospolitej w XVII stuleciu. Na skutek rozrzucenia informacji pomiędzy punkty dotyczące oficyn różnowierczych i poszczególnych ośrodków miejskich, trudno czytelnikom uchwycić całość zagadnienia nawet w encyklopedycznym zarysie, co z pewnością utrudnia poznanie złożonej i ciekawej tematyki, a u mniej wnikliwych użytkowników Wikipedii efektem są najprawdopodobniej braki w wiedzy.

Historia drukarstwa polskiego XV-XVI w. w Wikipedii została opisana w sumie w 39 artykułach, przynajmniej tyle udało się odszukać. Ze względu na nieprecyzyjne kategorie i błędy w hasłach możliwe, że część pominięto. Większość z nich stanowią biogramy poszczególnych typografów, dalej dzieje drukarń jako instytucji, wreszcie opisy dziejów drukarstwa w ośrodkach miejskich. Część $\mathrm{z}$ tekstów pokrywa się pod względem treści, np. w haśle dotyczącym jednego z pierwszych drukarzy na ziemiach polskich i pierwszego w ogóle, który drukował cyrylica, Szwajpolta Fiola i drukarni Szwajpolta Fiola. Zdarzają się też hasła powtórzone ze względu na błędne podanie nazwy drukarni, np. pierwsza żydowska oficyna na ziemiach polskich, drukarnia Heliczów (Drukarnia Heliczów) opisana także pod hasłem drukarnia Haliczów (Drukarnia Haliczów) (dodatkowo z błędną datą rozpoczęcia działalności).

Poszczególne artykuły mają różną objętość i charakter, od krótkich jednozdaniowych notek, po obszerne opisowe teksty. Do najbardziej lakonicznych należą biogramy Łazarza Andrysowicza (Łazarz Andrysowicz), 
czy królewieckich drukarzy Jana Weinreicha (Jan Weinreich) i Aleksandra Augezdeckiego (Aleksander Augezdecky). O Weinreichu - gdańszczanin z pochodzenia i tam wcześniej aktywny, pierwszy impresor w Królew$\mathrm{cu}$, drukował po polsku, litewsku, niemiecku i łacinie oraz w narzeczu staropruskim (Drukarze dawnej Polski, 1962, s. 447-462), drukarz pierwszej książki w języku litewskim (Žukas, 1997) - dowiemy się z Wikipedii tylko tyle: "Jan Weinreich (ur. ok. 1490, zm. 1560) - drukarz królewiecki. W latach 1523-1553 prowadził w Królewcu drukarnię. Wydał m.in. dzieła Jana Seklucjana i innych polskich pisarzy reformacyjnych, ogółem 13 pozycji w języku polskim" (Jan Weinreich).

Augezdecki, drukarz pierwszej postylli w języku polskim, sprowadzony do Królewca, by służyć propagowaniu luteranizmu wśród Polaków (Drukarze dawnej Polski, 1962, s. 26), został skwitowany dwoma lakonicznymi zdaniami. Notki o nim należy szukać pod hasłem Aleksander Augezdecky, a nie pod wersją przyjętą w literaturze przedmiotu, czyli Augezdecki.

Obszerniejsze i uzupełnione materiałem graficznym oraz pomocniczym, co ułatwia dotarcie do publikacji zewnętrznych, które były podstawą powstania artykułów, są m.in. te dotyczące Kaspra Elyana, drukarza pierwszych tekstów w języku polskim, trzech modlitw w „Statutach synodalnych biskupów wrocławskich" z 1475 r. (Kasper Elyan), Jana Januszowskiego (Jan Januszowski) lub Iwana Fedorowa (Iwan Fedorowicz), drukarza słynnej i wspaniale wyposażonej, tłumaczonej na język staro-cerkiewno-słowiański Biblii Ostrogskiej, jak zgodnie twierdzą historycy książki - najwspanialszego druku ruskiego XVI stulecia.

Artykuły w internetowej encyklopedii przypisywane są do tzw. kategorii. Ich autorzy nie są jednak konsekwentni w przyporządkowywaniu treści dotyczących historii polskich drukarń XV-XVI w. Znaleźć je można w kilku różnych, niepołączonych ze sobą działach: drukarnie, drukarnie w Polsce z podkategorią nieistniejące drukarnie w Polsce, drukarstwo staropolskie, drukarze, nieistniejące polskie wydawnictwa, polscy drukarze. Część z haseł nie została przypisana do żadnej z kategorii.

Jednym z istotnych minusów Wikipedii, zwłaszcza, gdy myślimy o jej roli popularyzatorskiej, jest kwestia zbyt swobodnego odwoływania się do literatury przedmiotu i podawania bibliografii. Zazwyczaj autorzy pomijają informatory dziedzinowe z zakresu bibliologii, a nieraz w ogóle nie umieszczają informacji bibliograficznych. Autor wspomnianego już tekstu na temat oficyny Haliczów (nie: Heliczów) nie umieścił ani jednej cytaty bibliograficznej, to samo w przypadku lakonicznej wzmianki o Łazarzu Andrysowiczu. W sumie w pięciu artykułach nie podano bibliografii. W pozostałych rzadko pojawiają się odwołania do informatorów dziedzinowych takich jak Encyklopedia wiedzy o ksiażce (3), Drukarze dawnej Polski (3), Słownik pracowników książki polskiej (3). Częściej autorzy sięgali do literatury bibliologicznej podręcznikowej i monografii (w sumie w 13 artykułach). Naj- 
częściej odsyłali do podręcznika Heleny Szwejkowskiej Ksiażka drukowana XV-XVIII wieku (różne wydania z lat 1975-1983). Ponadto w bibliografiach załączonych do artykułów znaleźć można opisy ogólnych informatorów, słowników i encyklopedii regionalnych i dziedzinowych (11) oraz największą grupę opracowań tematycznych dotyczących historii regionalnej, Kościoła oraz zagadnień dziedzinowych (14). Można ubolewać, że autorzy, wydawałoby się osoby zainteresowane dziejami książki polskiej, najwyraźniej rzadko kiedy mają świadomość istnienia takich ważnych i wiarygodnych prac jak Drukarze dawnej polski, czy Słownik pracowników ksiażki polskiej. Brak jest tym istotniejszy, że bibliografia służy internautom, którzy żądni wiedzy, pragną ją poszerzać i szukają innych źródeł niż krótkie artykuły encyklopedyczne. Ponad to odesłanie do literatury zewnętrznej daje łatwą możliwość weryfikacji treści w razie wątpliwości. Jest też niezmiernie ważne ze względu na promowanie wartościowej literatury, tworzenie kanonu tekstów, po które należy sięgać, czyli właśnie ze względu na popularyzację nauki.

\section{BŁĘDY, CZYLI WIKIPEDIA W KSZTAŁCENIU BIBLIOTEKOZNAWCZYM}

Konstrukcja serwisu, jakim jest Wikipedia, oraz forma oddolnego, społecznościowego i zdecentralizowanego tworzenia treści, skutkują rozproszeniem materiału, stosowaniem różnych kategoryzacji do zjawisk należących do tego samego obszaru, nierównomiernym rozłożeniem ciężaru pomiędzy artykułami o tej samej wadze. Dla użytkowników przyzwyczajonych do tradycyjnych encyklopedii $z$ artykułami opracowanymi według jednolitych regut, uporządkowanymi według jednego kryterium, z aparatem pomocniczym, zweryfikowanymi przez kolegia redakcyjne, budowa i zawartość Wikipedii mogą się okazać nie do przyjęcia.

Dostrzegalne braki, pomyłki, błędy, jakie można znaleźć w artykułach Wikipedii odnoszących się do historii książki polskiej XV-XVI w., ale także w innych artykułach związanych z historią książki i bibliotek, mogą stawiać pod znakiem zapytania wartość tej internetowej encyklopedii dla popularyzacji zagadnienia, a tym bardziej dla edukacji formalnej. Mamy bowiem do czynienia z publikacją która fałszuje obraz dawnego polskiego drukarstwa. Z drugiej strony dostrzegalna jest też wartość pisania o bibliologii historycznej $\mathrm{w}$ tak popularnym serwisie oraz to, że część artykułów jest gruntownie przygotowana, a dostrzeżone przeinaczenia poprawione $w$ kolejnych edycjach. Skoro jednak internauci podchodzący z zaufaniem do Wikipedii odchodzą od komputerów z niekompletnymi i po części fałszywymi informacjami, czy popularność nie jest minusem serwisu?

Prezentowany w Wikipedii zasób wiedzy o dawnym drukarstwie polskim jest niekompletny, a nieraz niezgodny z dzisiejszą wiedzą. Oczywiście jest to wada. Czy jednak zawsze? Jak można tę wadę wykorzystać? 
Encyklopedia o charakterze powszechnym nie jest i nie będzie miejscem zdobywania obszernej, a zarazem szczegółowej wiedzy fachowej. Powinna dać podstawową informację i zachęcić do dalszych poszukiwań. Wikipedia daje jednak więcej, mianowicie szansę weryfikacji treści, które zawiera i wydaje się, że jest to kluczowe nie tylko ze względu na budowanie treści, ale nawet bardziej ze względu na kształtowanie postaw użytkowników. Wikipedia jest efektem działania prosumentów, wspólnym dziełem, jednym z dzieci nowego modelu uczestniczenia w kulturze za pośrednictwem technologii cyfrowych. Jest częścią zjawiska Web 2.0

Według Grzegorza Gmiterka, który precyzuje pojęcie Web 2.0 na podstawie wcześniejszych definicji, „zjawisko to należy rozumieć nie jako nowy rodzaj witryny internetowej, ale raczej umiejętność i gotowość użytkowników do modyfikowania stron, z których w danym momencie korzystają. W takim rozumieniu Web 2.0 stanowi ważną rewolucję, a zarazem powrót do pierwotnych korzeni i cech Internetu" (Gmiterek, 2012, s. 43-44). Wikipedia, obok blogów i serwisów społecznościowych, jest zatem obszarem oddolnego współtworzenia treści Internetu. Jej znaczenie jest tym większe, że przejęła rolę tradycyjnych encyklopedii, których artykuły powstawały pod piórami autorytetów, ludzi nauki, doświadczonych edytorów. Mało tego, jak twierdzą badacze zagadnienia przywoływani chociażby przez Dariusza Jemielniaka, Wikipedia przyczynia się do zmian w powszechnym postrzeganiu autorytetów. Jemielniak cytuje jednego z autorów, który ukazuje ewolucję autorytetów, w którą Wikipedia ma swój wkład: „Wikipedia de facto zapowiada zmianę w naturze autorytetów. Przed erą Britanniki większość encyklopedii wywodziła swój autorytet od autora. Na scenie pojawiła się Britannica i dokonała całkiem radykalnego zapewnienia, że autorytet może też spoczywać $w$ rękach instytucji. [...] Wikipedia za to sugeruje, że autorytet można utożsamić z widocznym procesem. Jeśli widzi się, jak działa Wikipedia i zauważa się akceptowalne rezultaty jej działania, można jej w dłuższej perspektywie zaufać" (Jemielniak, 2013, s. 269). Jej rola, i to rola globalna, jest zatem wyjątkowo istotna, a treści artykułów budują świadomość tysięcy odbiorców. Jednak nie tylko, Wikipedia, powiedzmy po raz kolejny, jest miejscem aktywności kulturalnej, intelektualnej, twórczej jej użytkowników.

Wikipedia a także inne narzędzia Wiki wykorzystywane są przez internautów do uczestnictwa w kulturze. Współtworzenie internetowej encyklopedii nie ogranicza się jedynie do pisania i edytowania artykułów. Z aktywnością w serwisie wiąże się też udział w dyskusjach, czy, w dalszym efekcie, tworzenie forów i serwisów tematycznych, wreszcie posługiwanie się narzędziami Wiki do organizacji wydarzeń kulturalnych.

Paradoksalnie błędy i braki Wikipedii, ale też jej szczególną formę i rolę, różnorodne funkcje dostępnych narzędzi można i warto spróbować wykorzystać w dydaktyce, w tym przypadku w dydaktyce z zakresu historii 
książki i bibliotek. Najlepszym punktem wyjścia wydają się właśnie słabe merytorycznie i formalnie artykuły. Na ich przykładzie najłatwiej zrealizować zajęcia według następujących punktów: 1 . wyszukiwanie artykułów związanych z historią książki i bibliotek; 2 . kwerenda oraz idąca za nią lektura literatury, w efekcie której studenci nabywają wiedzę na temat przedmiotowego zagadnienia; 3. krytyka artykułu i weryfikacja błędów; 4. nauka edytowania artykułów lub pisania nowych; 5. poprawianie istniejących, tworzenie nowych treści w Wikipedii.

W trakcie realizacji pierwszego etapu prace studentów byłyby inspirowane przez prowadzącego, który wskazywałby, jakich postaci, czy faktów z historii drukarstwa należy w Wikipedii szukać. Wtedy też omówiona zostałaby podstawowa lektura przedmiotu i zasugerowane wartościowe publikacje. Kolejny krok należałby już do samych studentów i byłby kwerendą w znanych im źródłach informacji, po części w omówionych na wcześniejszym etapie: podręcznikach i skryptach do historii książki, informatorach takich jak Słownik pracowników ksiażki polskiej, czy chociażby Encyklopedia wiedzy o ksią̇ce oraz Polski słownik biograficzny, następnie w katalogach i bibliografiach (zwłaszcza specjalnych) poprzez indeksy przedmiotowe i to zarówno w wersjach tradycyjnych, jak i elektronicznych. Będzie to etap doskonalenia kompetencji informacyjnych, wyszukiwania informacji i jej porządkowania pod kątem wyznaczonego zadania. Po nim powinno nastąpić zapoznanie się z wybraną literaturą przedmiotu i porównanie treści zawartej w tekstach naukowych, słownikach, encyklopediach z zawartością Wikipedii, wyłowienie pomyłek, braków i nieścisłości, wreszcie ich poprawienie. Na tym etapie studenci doskonalić będą umiejętność z jednej strony krytycznego spojrzenia na informację i analizy tekstów, a z drugiej tworzenia krótkich, syntetycznych, przejrzystych i uporządkowanych tekstów informacyjnych. Dodatkową wartością będzie umiejętność czysto techniczna pomnażania zasobów sieciowych, wprowadzanie nowych treści.

W trakcie tak realizowanych zajęć studenci nie tylko zdobywać będą wiedzę na temat historii drukarstwa, książki i bibliotek, ale też nabywać i/lub doskonalić już posiadane umiejętności porządkowania wiedzy, konstruowania zwięzłych tekstów informacyjnych, wyszukiwania informacji i sporządzania bibliografii oraz przypisów. Jednak przede wszystkim celem tak realizowanych ćwiczeń będzie uświadomienie słuchaczom konieczności krytycznego podejścia do informacji, wykształcenie potrzeby weryfikowania źródeł wiedzy poprzez odkrywanie cudzych błędów, niedociągnięć, czy nawet manipulacji. Współzawodnictwo z innymi wikipedystami może pełnić rolę dodatkowego elementu motywacyjnego.

Autorstwo haseł w Wikipedii oraz ich edytowanie w celu naniesienia poprawek, udział w dyskusjach, uzupełnianie zasobów graficznych encyklopedii przez współtworzących ją społecznie użytkowników jest również 
włączeniem się w tworzenie dóbr kultury dostępnych za pośrednictwem Internetu, a zarazem promocją kultury poprzez informowanie o zabytkach, wydarzeniach, czy chociażby historii dawnej książki. Zatem kolejnym efektem zajęć będzie wykształcenie w słuchaczach potrzeby aktywnego uczestnictwa w kulturze poprzez tworzenie i popularyzację jej treści także po ukończeniu studiów. Jest to szczególnie pożądane u przyszłych pracowników instytucji kultury. Innym z celów będzie zainicjowanie głodu wiedzy, kataliza potrzeby uczenia się przez całe życie, dbałości o rozwój intelektualny.

\section{BIBLIO-I NETOGRAFIA}

Aleksander Augezdecky [online]. Wikipedia. [dostęp: 12.09.2015]. Dostępny w WWW: <https:// pl.wikipedia.org/wiki/Aleksander_Augezdecky>.

Almanach cracoviense ad annum 1474 [online]. Wikipedia. [dostęp: 16.09.2016]. Dostępny w WWW: <https://en.wikipedia.org/wiki/Almanach cracoviense ad annum 1474>.

Drukarnia Haliczów [online]. Wikipedia. [dostęp: 12.09.2015]. Dostępny w WWW: <https:// pl.wikipedia.org/wiki/Drukarnia_Haliczów>.

Drukarnia Heliczów [online]. Wikipedia. [dostęp: 12.09.2015]. Dostępny w WWW: <https:// pl.wikipedia.org/wiki/Drukarnia_Heliczów>.

Drukarnia Łazarzowa [online]. Wikipedia. [dostęp: 12.09.2015]. Dostępny w WWW: <https:// pl.wikipedia.org/wiki/Drukarnia_Łazarzowa>.

Drukarstwo polskie. Drukarstwo w XVI wieku [online]. Wikipedia. [dostęp: 12.09.2015]. Dostępny w WWW: <https://pl.wikipedia.org/wiki/Drukarstwo_polskie\#Drukarstwo_w_ XVI_wieku>.

Drukarstwo polskie. Gdańsk [online]. Wikipedia. [dostęp: 12.09.2015]. Dostępny w WWW:<https://pl.wikipedia.org/wiki/Drukarstwo_polskie\#Gda.C5.84sk>.

Drukarstwo polskie: różnice pomiędzy wersjami [online]. Wikipedia. [dostęp: 12.09.2015]. Dostępny w WWW: <https://pl.wikipedia.org/w/index.php?title=Drukarstwo_polskie\&type=revision\&diff $=42345323 \&$ oldid $=13372208>$.

Drukarstwo polskie: różnice pomiędzy wersjami [online]. Wikipedia. [dostęp: 12.09.2015]. Dostępny w WWW: <https://pl.wikipedia.org/w/index.php?title=Drukarstwo_polskie\&type=revision\&diff $=34937348 \&$ oldid $=13372208>$.

Drukarze dawnej Polski od XV do XVIII wieku. T. 1: Małopolska. Cz. 1: Wiek XV-XVI. (1983). Praca zbior. pod red. Alodii Kaweckiej Gryczowej. Wrocław: Zakład Narodowy im. Ossolińskich Wydaw. Polskiej Akademii Nauk.

Drukarze dawnej Polski od XV do XVIII wieku. T. 4: Pomorze. (1962). Oprac. Alodia Kawecka-Gryczowa oraz Krystyna Korotajowa. Wrocław: Zakład Narodowy im. Ossolińskich Wydaw. Polskiej Akademii Nauk.

Główny Urząd Statystyczny (2015). Społeczeństwo informacyjne w Polsce w 2015 r. [dostęp: 15.02.2017]. Dostępny w WWW: <http://stat.gov.pl/obszary-tematyczne/nauka-i-technika-spoleczenstwo-informacyjne/spoleczenstwo-informacyjne/spoleczenstwo-informacyjne-w-polsce-w-2015-r-,2,5.html>.

Główny Urząd Statystyczny. Wydział Statystyki Edukacji, Statystyki Kultury i Organizacji Non-profit (oprac.): Uczestnictwo ludności w kulturze w 2009 r. Warszawa 2012, s. 59-60. 
Gmiterek, Grzegorz (2012). Biblioteka w środowisku społecznościowego Internetu. Biblioteka 2.0. Warszawa: Wydaw. SBP.

Iwan Fedorowicz [online]. Wikipedia. [dostęp: 12.09.2015]. Dostępny w WWW: <https://pl.wikipedia.org/wiki/Iwan_Fedorowicz>.

Jan Januszowski [online]. Wikipedia. [dostęp: 12.09.2015]. Dostępny w WWW: <https://pl.wikipedia.org/wiki/Jan_Januszowski>.

Jan Weinreich [online]. Wikipedia. [dostęp: 12.09.2015]. Dostępny w WWW: <https://pl.wikipedia.org/wiki/Jan_Weinreich>.

Jemielniak, Dariusz (2013). Życie wirtualne dzikich. Netnografia Wikipedii największego projektu wspóttworzonego przez ludzi. Warszawa: Poltext.

Kasper Elyan [online]. Wikipedia. [dostęp: 12.09.2015]. Dostępny w WWW: <https://pl.wikipedia.org/wiki/Kasper_Elyan>.

Kawecka-Gryczowa, Alodia (1971). Dzieje „Drukarni latającej”. Rocznik Biblioteki Narodowej, VII, s. 355-370.

Łazarz Andrysowicz [online]. Wikipedia. [dostęp: 12.09.2015]. Dostępny w WWW: <https:// pl.wikipedia.org/wiki/Łazarz_Andrysowicz>.

Majewski, Tomasz (2013). Ekskluzja w dyskursie pracowników sektora kultury - wstępna próba interpretacji. W: Oblicza ekskluzji. Praktyka działania instytucji kultury a przełamywanie barier dostępu. Pod red. Ewy Rokickiej i Patrycji Kruczkowskiej. Łódź: Katedra Socjologii Ogólnej Uniwersytetu Łódzkiego, s. 20-27.

McLuhan, Marshall; Nevitt, Barrington (1972). Take today. The executive as Dropout. New York: Harcourt Brace Jovanovich.

Migoń, Krzysztof (2007). Bibliologia wśród innych nauk. Koncepcje, realizacje, perspektywy. W: Bibliologia. Problemy badawcze nauk humanistycznych. Praca zbior. Pod red. Dariusza Kuźminy. Warszawa 2007, s. 13-24.

Migoń, Krzysztof (2008). O współczesnej sytuacji badawczej w naukach o książce, bibliotece i informacji. Przeglad Biblioteczny, z. 1, s. 14-21.

MNW wspótpracuje z Wikimedia Polska [online], [dostęp: 12.09.2015]. Dostępny w WWW: <http://www.mnw.art.pl/aktualnosci/mnw-wspolpracuje-z-wikimedia-polska,230.html>.

Mobile online w Polsce 2015. Perspektywy rozwojowe (2015) [online], [dostęp: 12.09.2015]. Dostępny w WWW <https://iab.org.pl/wp-content/uploads/2015/04/Book_Raport_mobile_2015.pdf>.

Odprawa posłów greckich [online]. Wikipedia. [dostęp: 12.09.2015]. Dostępny w WWW: $<$ https://pl.wikipedia.org/wiki/Odprawa_posłów_greckich>.

Piekarski, Kazimierz (1932). Książka w Polsce XV i XVI wieku. W: Kultura staropolska. Kraków: PAU, s. 352-384.

Rozporządzenie Ministra Nauki i Szkolnictwa Wyższego z dnia 8 sierpnia 2011 r. w sprawie obszarów wiedzy, dziedzin nauki i sztuki oraz dyscyplin naukowych u artystycznych (Dz.U. 2011 r. Nr 179, poz. 1065).

Statystyki Wikipedii [online], [dostęp: 12.09.2015]. Dostępny w WWW: <http://stats.wikimedia.org/PL/Sitemap.htm>.

Szarfenbergerowie (rodzina) [online]. Wikipedia. [dostęp: 12.09.2015]. Dostępny w WWW: $<$ https://pl.wikipedia.org/wiki/Szarfenbergowie_(rodzina)>.

Toffler, Alvin (2006).Trzecia fala. Warszawa: Wydaw. Kurpisz S.A.

Wikipedia: statystyki [online], [dostęp: 12.09.2015]. Dostępny w WWW: <https://pl.wikipedia.org/wiki/Wikipedia:Statystyki>. 
Wyniki badań Gemius/PBI za sierpień 2016 (2016) [online], [dostęp: 10.09.2016]. Dostępny w WWW <https://www.gemius.pl/wszystkie-artykuly-aktualnosci/wyniki-badania-gemiuspbi-za-sierpien-2016.html>.

Žukas, Saulûs (1997). Pervaâ litovskaâ kniga v kul'turnom kontekste épohi. Vilnius: Baltos Lankos.

Artykut w wersji poprawionej wptynąt do Redakcji 15 lutego 2017 r.

MIKOŁAJ OCHMAŃSKI

Faculty of Journalism, Information and Book Studies

University of Warsaw

e-mail: mikolaj.ochmanski@gmail.com

\section{IS WIKIPEDIA USEFUL IN TEACHING THE HISTORY OF BOOKS AND LIBRARIES?}

KEYWORDS: Book studies. Wikipedia. History of books. History of printing. Teaching the library studies.

ABSTRACT: Thesis/Objective - The author discusses Wikipedia as a source of information on the history of Polish books in the fifteenth and sixteenth century and its usefulness for the dissemination of knowledge on the history of books and teaching the library studies. The selection of Wikipedia entries was analyzed, mistakes and gaps were identified and their corrections done by wikipedists were described. The author offers some suggestions how to use Wikipedia with all its mistakes and benefits in teaching the history of books. Research methods - The article is based on Wikipedia entries for the history of Polish books and printing in the fifteenth and sixteenth century. The critical analysis of the Wikipedia content was used. Results/Conclusions - The author identifies mistakes in Wikipedia entries and questions the informative value of this resource as regards the history of books, points to the benefits from the collaborative construction of its content and shows the possibilities of using Wikipedia as a teaching aid in library and information studies. 